\title{
PEMULIHAN TRAUMATIK TERHADAP PENYINTAS YANG MENGALAMI PELECEHAN SEKSUAL DI MASA KANAK-KANAK DI SEKOLAH TINGGI THEOLOGIA JAFFRAY MAKASSAR
}

\author{
Betty Huang ${ }^{1}$ \\ Ivone Patti Palar ${ }^{2}$
}

\begin{abstract}
ABSTRAK
Tujuan penulisan karya ilmiah ini adalah: Pertama, untuk mengenali dampak traumatik yang dialami oleh mereka yang mengalami pelecehan seksual. Kedua, untuk menemukan cara-cara pemulihan bagi penyintas terhadap dampak traumatik yang dialami karena pelecehan seksual tersebut.

Adapun metode penulisan yang digunakan adalah: metode penelitian kuantitatif dengan teknik pengumpulan data dan analisis data dengan observasi langsung, penyebaran angket, dan wawancara.

Adapun kesimpulan karya ilmiah ini adalah: Pertama, dampak negatif yang dialami anak-anak akibat pelecehan seksual akan mendatangkan trauma jangka panjang yang disebut juga Post Traumatic Stress Disorder (PTSD) atau Penyimpangan Jiwa Akibat Tekanan Traumatik (PJATT). Kedua, salah satu pintu pemulihan adalah dengan mengenal pokok permasalahan, memiliki sikap keterbukaan, dan melibatkan Allah dalam proses pemulihan. Ketiga, proses pengobatan dan pemulihan dapat terjadi bila dilakukan dengan menggunakan pelayanan holistik yaitu pelayanan medis, pelayanan psikologis, pelayanan hukum atau advokasi (pendampingan), dan pelayanan rohani.
\end{abstract}

Kata Kunci: pemulihan traumatik, penyintas, pelecehan seksual, masa kanak-kanak

\footnotetext{
${ }^{1}$ Alumni S1 STT Jaffray Makassar 2013

${ }^{2}$ Dosen STT Jaffray Makassar konsentrasi Pelayanan Anak dan Remaja
} 


\section{PENDAHULUAN}

\section{Latar Belakang Masalah}

Ketika seseorang berkomunikasi di mana saja dan kapan saja dikalangan anak-anak hingga orang dewasa akan menemukan simbol senyum untuk menyatakan ekspresinya dalam berbagai media yang digunakan. Sudah pasti orang yang menerima simbol senyum tersebut akan memperlihatkan wajah yang tersenyum juga. Firman Tuhan menyatakan bahwa, "Hati yang gembira membuat muka berseri-seri, tetapi kepedihan hati mematahkan semangat" (Amsal 15:13). Maka, orang percaya dalam segala aspek kehidupan harus memperlihatkan wajah yang tersenyum. Tetapi suasana seperti ini tidak dirasakan oleh RI (singkatan nama) akibat pelecehan seksual yang dialaminya. Wajah tersenyum tidak terlihat lagi diwajah bocah kecil ini.

Maraknya kasus pelecehan seksual yang muncul di berbagai media massa telah menjadi topik yang hangat untuk dibicarakan, diantaranya adalah kasus pelecehan seksual yang dialami oleh seorang anak wanita berusia 11 tahun, berinisial RI telah diperkosa beberapa kali oleh ayah kandungnya. Akibat perbuatan ayah kandungnya, RI menderita kesakitan. RI dibawa berobat oleh ibunya ke puskesmas dan klinik. RI mengalami infeksi di kemaluannya. Kemudian RI di rujuk ke Rumah Sakit Umum Pusat Persahabatan (RSUP) dokter menemukan ada luka di vagina dan anus RI, disebabkan virus yang ditularkan melalui hubungan seksual. Anak yang polos, dan ceria berujung pada kematian akibat perbuatan ayah kandung. Canda tawa tidak terdengar lagi di rumah RI, bahkan senyuman diwajahnya tidak terlihat lagi. Sekeluarga dirundung kesedihan akibat perbuatan ayah kandung, RI mengalami trauma hingga nyawanya tidak dapat tertolong lagi.

Bagi beberapa orang dewasa, anak dianggap sebagai orang yang harus tunduk pada orang tuanya, anak menjadi korban kekerasan orang tuanya. Dalam situasi yang mendesak, anak diperdagangkan oleh orang tuanya, ada juga anak yang dianiaya oleh orang tuanya, dan lain sebagainya. Statistik atau data dari surat kabar Kompas menjelaskan bahwa jumlah anak-anak yang membutuhkan perlindungan adalah:

Sedikitnya ada 37 juta anak dari 70 juta anak Indonesia yang saat ini berada dalam situasi membutuhkan perlindungan khusus dari segala bentuk eksploitasi, diskriminasi, kekerasan, dan penelantaran. Dari data tersebut 1,6 juta anak terpaksa harus bekerja dan kehilangan hak-haknya. Mereka harus kepanasan, kehujanan, kedinginan, kelaparan bahkan kadang sampai mati untuk bertahan hidup. Begitu besarnya permasalahan anak-anak yang berkembang saat ini, bukan hanya karena deraan krisis 
multidimensi tapi juga akibat konflik-konflik yang merebak di beberapa daerah tahun ini memaksa pemerintah untuk segera meratifikasi Undang-Undang Perlindungan Anak (UUPA) yang baru. Dengan UUPA yang baru ini diharapkan hak-hak anak-anak Indonesia yang selama ini diabaikan mulai dapat terpenuhi karena adanya perlindungan dari instansi yang jelas."

"Undang-undang Republik Indonesia nomor 23 tahun 2002 tentang perlindungan anak, Bab 1 pasal 1 ayat 2 dan 12 Perlindungan anak adalah segala kegiatan untuk menjamin dan melindungi anak dan hak-haknya agar dapat hidup, tumbuh, berkembang, dan berpartisipasi, secara optimal sesuai dengan harkat dan martabat kemanusiaan, serta mendapat perlindungan dari kekerasan dan diskriminasi. Hak anak adalah bagian dari hak asasi manusia yang wajib dijamin, dilindungi, dan dipenuhi oleh orang tua, keluarga, masyarakat, pemerintah, dan negara.."

"Berbagai undang-undang dan sistem hukum di Indonesia perlu dikaji ulang agar tidak ada berbenturan antara pemenuhan hak-hak anak dengan pelaksanaan kehidupan bersama sebagai bangsa yang diatur oleh berbagai undang-undang dan kerangka hukum lainnya." " Undangundang di Indonesia hanyalah tinggal undang-undang saja, tanpa ada pelaksanaannya. Padahal anak-anak merupakan regenerasi bangsa. Anak-anak selalu diabaikan atau dinomor urutkan pada bagian-bagian yang terakhir, termasuk dari pihak gereja pada umumnya tidak memperhatikan kebutuhan anak-anak atau sekolah minggu.

Diantara beberapa orang percaya maupun bukan orang percaya yang mengalami pelecehan seksual tidak terlihat lagi wajah-wajah yang tersenyum. Banyak anak-anak yang mendapat pelecehan seksual dari orang-orang terdekatnya, seperti ayah kandung, ayah tiri, paman, kakek, saudara laki-laki, tetangga, dan lain pihak. Anak yang mengalami pelecehan seksual, saat itu juga kehidupannya akan berubah dan hancur. Hidupnya tidak akan sama lagi. demikian:

Seperti contoh kasus yang dipaparkan oleh Diane Langberg

"Kehidupan saya yang tenteram di pedesaan hancur ketika saya baru berumur delapan tahun. Pada suatu hari saya adalah murid kelas tiga SD yang berbahagia, ceria, percaya terhadap segala

\footnotetext{
${ }^{3}$ Sarumpaet Riris K. Toha, "Anak Adalah Harta Yang Berharga," Warta Sumber Hidup 6 (Maret-Mei 2003), 7.

${ }^{4}$ Kementerian Pemberdayaan Perempuan dan Perlindungan Anak Republik Indonesia, (n.p.:n.d., 2011), 5-6.

${ }^{5}$ Tri Budiardjo, Pelayanan Anak Yang Holistik (Yogyakarta: ANDI, 2011), 59.
} 
sesuatu, suka bepergian, tetapi keesokan harinya saya menjadi orang yang berbeda. Meskipun pada waktu itu saya tidak mengerti, namun, kehidupan saya tidak akan pernah sama lagi."

Contoh kasus yang kedua

Seorang korban kekerasan seksual yang bertahan hidup lainnya melukiskan bagaimana kehidupannya berubah karena kekerasan seksual itu, "Bila saya sedang takut, saya akan berlari kepada ayah saya untuk mendapatkan rasa aman. Saya sangat merindukan tempat yang tenteram bila saya sedang takut. Kemudian ayah saya menidurkan saya dipangkuannya dan mengatakan bahwa segalanya akan baik kembali. Namun kemudian segalanya berubah. Bukannya memberi saya keteduhan dan perlindungan dari ketakutan saya, ayah saya justru mengambil keuntungan dari kerapuhan saya itu dan mulai menggunakan tubuh saya demi kesenangan seksualnya. Saya mengulurkan tangan untuk mencari ketentraman, justru mendapatkan kekerasan seksual. ${ }^{\top}$

Kedua kasus pelecehan seksual yang dialami membawa mereka pada situasi luka batin yang berkepanjangan. Penulis pada usia sembilan tahun mengalami pelecehan seksual sentuhan fisik dari tetangga, kehidupan penulis berubah menjadi trauma. Semasa penulis Praktek Kerja Lapangan (PKL) di daerah kabupaten Keerom-Perbatasan Papua Nugini desa Woslay menemukan anak usia empat tahun diperkosa oleh pamannya. Masih banyak kasus pelecehan seksual yang dialami oleh anak-anak.

"Dengan luka batin terus-menerus memikirkan peristiwa yang dialaminya. Sesekali mereka merasa kembali berada ditengah kejadian itu, seolah-olah mereka menjalaninya kembali. Ini biasa terjadi baik dalam keadaan sadar maupun dalam tidur, sebagai mimpi buruk. Mengingat-ingat kejadian tersebut berulang kali menyulitkan mereka untuk berkonsentrasi kepada satu tugas tertentu."

"Hubungan hubungan masa lalu kita mungkin melibatkan rasa sakit yang mendalam akibat pengabaian, pelecehan seksual, dan manipulasi, tetapi jika kita tidak memulai proses penyembuhan, kita 2008), 20

${ }^{6}$ Diane Langberg, Di Ambang Pintu Pengharapan (Jakarta:BPK Gunung Mulia,

${ }^{7}$ Ibid, 20.

${ }^{8}$ Margaret Hill et al., Menyembuhkan Luka Batin Akibat Trauma (Jakarta:Kartidaya dan Yogyakarta: Gloria Graffa, 2006), 36. 
tidak akan mampu mengalami sukacita, tantangan, dan akan menuju kegagalan masa kini." Pelecehan seksual bukan saja dialami oleh anakanak yang ada di luar sana, tapi juga anak-anak di gereja. Bahkan beberapa mahasiswa Sekolah Tinggi Theologia Jaffray Makassar pun di masa kanak-kanak mereka mengalami pelecehan seksual dan menyebabkan dampak traumatik berkepanjangan. Beberapa di antaranya belum dipulihkan dari trauma masa lalu tersebut.

Berdasarkan latar belakang di atas, maka penulis tertarik untuk menulis karya ilmiah dengan judul: "Pemulihan Traumatik Terhadap Penyintas Yang Mengalami Pelecehan Seksual Di Masa Kanak-Kanak Di Sekolah Tinggi Theologia Jaffray Makassar."

\section{Pokok Masalah}

Dengan melihat latar belakang masalah di atas, maka pertanyaan yang kemudian timbul adalah:

Pertama, apa dampak traumatik bagi penyintas yang mengalami pelecehan seksual?

Kedua, bagaimana penanggulangan dan pertolongan penyintas sehingga dapat pulih dari traumatik akibat pelecehan seksual yang terjadi di masa kanak-kanak?

\section{Tujuan Penulisan} ini adalah:

Ada pun tujuan yang ingin dicapai dalam penulisan karya ilmiah

Pertama, untuk mengenali dampak traumatik yang dialami oleh mereka yang mengalami pelecehan seksual.

Kedua, untuk menemukan cara-cara pemulihan bagi penyintas terhadap dampak traumatik yang dialami karena pelecehan seksual tersebut.

\section{Manfaat Penulisan}

Adapun manfaat dari karya ilmiah ini adalah:

Pertama, karya ilmiah ini diharapkan dapat memberi manfaat bagi para hamba-hamba Tuhan yang pernah dan akan membimbing orangorang Kristen dengan masalah pelecehan seksual.

Kedua, bermanfaat bagi para guru-guru sekolah yang sedang dan akan membina anak didiknya.

Ketiga, untuk menunjang pelayanan penulis terutama bagi anakanak yang pernah mengalami traumatik pelecehan seksual.

\section{Metode Penelitian}

\footnotetext{
${ }^{9}$ Robert S. McGee, Pemulihan Gambar Diri (Jakarta:Metanoia, 1998), 109.
} 
Upaya-upaya yang dilakukan untuk kelengkapan karya ilmiah ini, maka penulis menggunakan metode antara lain:

Pertama, studi pustaka di mana penulis akan meneliti buku-buku yang berhubungan dengan topik pembahasan karya ilmiah ini.

Kedua, selain metode di atas penulis juga menggunakan teknik pengumpulan data dan analisis data dengan observasi langsung, penyebaran angket, dan wawancara.

\section{Batasan Penulisan}

Mengingat masalah pelecehan seksual sangat luas, maka penulis hanya membatasi pada dampak dan pemulihan traumatik terhadap penyintas yang pernah mengalami pelecehan seksual di masa kanakkanak. Anak-anak yang dimaksud adalah mereka yang berusia 3-12 tahun. Penyintas adalah mereka yang pernah mengalami pelecehan seksual di masa kanak-kanak namun mampu bertahan hidup hingga dewasa. Penyintas yang diamati adalah mahasiswa Sekolah Tinggi Theologia Jaffray (STTJ) Makassar.

\section{Pengertian Mengenai Pelecehan Seksual}

John Piper dan Justin Taylor mengatakan, "Seks itu baik karena Allah yang menciptakan seks itu baik. Dan Allah sangat dimuliakan ketika kita menerima karunia-Nya dengan rasa syukur dan menikmatinya sesuai dengan cara yang dimaksudkan-Nya." ${ }^{10}$ Namun seks yang Allah berikan kepada manusia itu telah rusak oleh dosa dan mengakibatkan perbuatan seks yang menyimpang, sehingga manusia tidak lagi menghargai seks sebagai pemberian Allah yang baik dan mulia. Menganggap seks itu hanya sebagai kepuasan fisik atau nafsu saja, maka untuk memenuhi kepuasannya manusia melakukan aksi pelecehan seksual terhadap orang lain.

\section{Definisi Tentang Pelecehan Seksual}

Berikut ini adalah beberapa pendapat yang mendefinisikan tentang pelecehan seksual, diantaranya adalah:

Menurut Kamus Besar Bahasa Indonesia pelecehan seksual berasal dari kata dasar, "leceh yang berarti remeh; tidak berharga; buruk kelakuan; dan hina. Pelecehan adalah proses, perbuatan, cara melecehkan." Seksual adalah berkenaan dengan seks (jenis kelamin); berkenaan dengan perkara persetubuhan antara laki-laki dan

\section{0.}

2008), 50

${ }^{10}$ John Piper dan Justin Taylor, Seks dan Supremasi Kristus (Surabaya: Momentum, 
perempuan." ${ }^{12}$ Jadi, pelecehan seksual adalah suatu perbuatan yang meremehkan atau berkelakuan buruk terhadap persetubuhan (tubuh sensitif) lawan jenis.

"Penyiksaan seksual didefinisikan sebagai keterlibatan dalan kegiatan seksual pada anak yang belum dapat mandiri, belum matang dalam perkembangan di mana mereka belum memahami sepenuhnya kaidah sosial yang berlaku, sehingga tidak dapat melaporkan penyiksaan secara khusus dan itu merupakan pelanggaran yang tabu di masyarakat terhadap peranan keluarga.,"13

Menurut Dan B. Allender pelecehan seksual adalah, "Kontak atau interaksi apa pun (visual, verbal, atau psikologi) antara seorang anak atau remaja dengan seorang dewasa, yang memanfaatkan anak atau remaja itu untuk rangsangan seksual pelaku atau orang lain..14

Pertama, Pelecehan seksual adalah segala bentuk perilaku maupun perkataan bermakna seksual yang berefek merendahkan martabat orang yang menjadi sasaran. Kedua, Pelecehan seksual adalah segala macam bentuk perilaku yang berkonotasi seksual yang dilakukan secara sepihak dan tidak diharapkan oleh orang yang menjadi sasaran hingga menimbulkan reaksi negatif: rasa malu, marah, tersinggung dan sebagainya pada diri orang yang menjadi korban pelecehan. ${ }^{15}$

Jadi kesimpulannya, pelecehan seksual adalah suatu perbuatan yang sengaja dilakukan oleh seseorang atau sekelompok orang terhadap pihak lain yang berkonotasi seksual, baik melalui perkataan langsung maupun lewat media, mempertontonkan alat kelamin, sentuhan, perkosaan yang merendahkan martabat dan harkat orang yang menjadi korban pelecehan atau yang disebut juga penyintas (survivor). Kata penyintas terjemahan dari survivor. "Istilah survive (yang berarti bertahan) berasal dari istilah Latin supervivere. Secara harfiah, kata itu berarti hidup melampaui kemampuan. To survive berarti tetap hidup menghadapi rintangan. Istilah ini memberi kesan adanya kemampuan

\footnotetext{
${ }^{12}$ Kamus Besar Bahasa Indonesia, s.v., "Seks” (Jakarta: Balai Pustaka, 2005), 1014.

${ }^{13}$ Hesti, Konseling Dan Terapi Dengan Anak Dan Orang Tua (Jakarta: Gravindo, n.d.), 94.

${ }^{14}$ Dan B. Allender, Hati Yang Luka Kemenangan Atas Derita Pelecehan Seksual (Jakarta: BPK Gunung Mulia, 2001), 33.

${ }^{15}$ Dewi, "Pelecehan Seksual”, diakses 25 Februari 2013; tersedia di http://dewiberbagiilmukebidanan.blogspot.com/2010/04/pelecehan-seksual.html
} 
untuk bertahan. Jadi, korban kekerasan seksual yang bertahan hidup adalah orang yang telah mengalami pengalaman luar biasa, tetapi mengatur dirinya agar tetap hidup.."16 Untuk selanjutnya penulis akan menggunakan istilah penyintas bagi mereka yang mengalami pelecehan seksual namun mampu bertahan dan dapat mengatur dirinya agar tetap hidup. Sedangkan istilah korban lebih mengacu kepada mereka yang seolah-olah tidak dapat ditolong, tidak memiliki harapan dan tidak bisa lagi hidup.

\section{Jenis-Jenis Pelecehan Seksual}

Ada beberapa jenis pelecehan seksual yang berhubungan dengan anak-anak. Jenis yang paling terkenal di banyak negara berkembang, secara khusus negara-negara berkembang di kawasan Asia Tenggara, adalah eksploitasi, yakni perdagangan seks komersial dan Paedofilia. Paedofilia adalah orang-orang dewasa, biasanya laki-laki, yang menginginkan hubungan seksual hanya dengan anak-anak. Setiap orang yang mengidap Paedofilia memiliki selera masing-masing akan usia dan jenis kelamin, tapi umumnya penyintas (survivor) Paedofilia adalah anak laki-laki. ${ }^{17}$

Pada umumnya pelecehan seksual dibagi menjadi dua kategori, yaitu: pelecehan seksual tanpa kontak langsung (sentuhan) atau tanpa kontak seksual; dan pelecehan seksual dengan kontak langsung.

\section{Pelecehan Seksual Tanpa Kontak Langsung (Sentuhan)}

Berikut ini adalah beberapa definisi dari pelecehan seksual tanpa kontak langsung (sentuhan) yang penulis ambil dari beberapa sumber, yaitu:

Menurut Bunga K. Kobong, pelecehan seksual tanpa kontak atau tanpa menyentuh adalah, "Memberikan dan menunjukkan gambargambar porno untuk merangsang fantasi penyintas. Mempertontonkan organ seksual kepada anak dan atau melakukan hubungan seksual di depan penyintas. Penggunaan kata-kata seksual yang merangsang dalam percakapan sehari-hari oleh pelaku. Menyuruh penyintas memegang benda-benda pelaku yang ada kaitannya dengan organ seksual seperti celana dalam, bra, dan lain-lain."18 2008), 19

${ }^{16}$ Diane Langberg, Di Ambang Pintu Pengharapan (Jakarta: BPK Gunung Mulia,

${ }^{17}$ Daughter: Modul VCD (Philippines: n.p., n.d.), 17.

${ }^{18}$ Bunga K. Kobong, "Diktat Kuliah Pelayanan Anak Beresiko" (Makassar: STT Jaffray, April 2009), 1-2. 
Menurut Dan B. Allender, Pelecehan seksual tanpa kontak langsung yaitu: Permintaan langsung untuk tujuan seks; permintaan atau sindiran rayuan (halus); penggambaran praktekpraktek seks; penggunaan bahasa seksual secara berulang-ulang dan istilah seksual sebagai nama pribadi. Memperlihatkan atau memanfaatkannya untuk pornografi; secara sengaja (berulangulang) memperlihatkan tindakan-tindakan seksual, alat kelamin, dan/ atau pakaian yang merangsang seks (BH, baju tidur, pakaian dalam); perhatian tidak senonoh yang ditujukan ke tubuh atau pakaian dengan tujuan rangsangan seksual. ${ }^{19}$

Stephen Arterburn, dan Jim Burns mengemukakan, "Pengalaman atau aktivitas seksual tanpa sentuhan meliputi: memperlihatkan materimateri pornografi kepada anak-anak, mengambil foto anak-anak dalam keadaan telanjang, seorang dewasa memperlihatkan tubuhnya yang telanjang kepada seorang anak atau kebalikannya." ${ }^{20}$

Jadi dapat disimpulkan beberapa perilaku yang termasuk dalam pelecehan seksual tanpa kontak langsung, yaitu:

(1) Exhibitionism yaitu mempertontonkan organ vital, termasuk memegang organ vital atau tubuh telanjang untuk mendapatkan kenikmatan seksual.

(2) Voyeurism yaitu menonton (mengintip) orang tanpa busana atau adegan seks, termasuk memegang atau mencium pakaian-pakaian dalam yang merangsang seks.

(3) Pornografi yaitu memperlihatkan gambar-gambar porno kepada anak-anak.

(4) Memperlihatkan tindakan-tindakan seksual, seperti: meminta anak melihat adegan seks, meminta anak telanjang, mengambil foto anak telanjang.

(5) Perhatian tidak senonoh yang ditujukan ke tubuh atau pakaian dengan tujuan rangsangan seksual.

(6) Penggunaan komunikasi seksual secara berulang-ulang, seperti rayuan berbau porno baik melalui telepon, SMS atau internet dengan menghilangkan privasi.

\footnotetext{
${ }^{19}$ Dan B. Allender, Hati Yang Luka Kemenangan Atas Derita Pelecehan Seksual (BPK Gunung Mulia, 2001), 37.

${ }^{20}$ Stephen Arterburn dan Jim Burns, Arahkan Dengan Jitu (Yogyakarta: ANDI, 2010), 115
} 


\section{Pelecehan Seksual Dengan Kontak Langsung (Sentuhan)}

Menurut Stephen Arterburn, dan Jim Burns, "Aktivitas seksual dengan sentuhan meliputi: meraba bagian-bagian tubuh orang lain yang bersifat pribadi, kontak alat kelamin, hubungan seks, dan perkosaan." ${ }^{21}$

Menurut Bunga K. Kobong, pelecehan dengan menyentuh atau kontak seksual adalah, Pelaku memanipulasi daerah-daerah sensitif dari tubuh penyintas (survivor) pada dada, organ seksual, tengkuk, mencium, dan lain-lain. Pelaku menyentuh bagian-bagian sensitif penyintas (survivor) dengan sengaja pada dada, pinggul, pantat, dan daerah pribadi seperti payudara dan organ genital seksual. Pelaku berhasil melalui bujukan mengadakan hubungan seksual dengan penyintas; pelaku mengancam dan karena itu bebas mengulangi perbuatannya. ${ }^{22}$

Pelecehan secara langsung atau dengan sentuhan yaitu yang termasuk ke dalamnya mencium, bersenang-senang, hubungan seks secara oral, vaginal atau anal, atau percobaan hubungan seksual.".23

Menurut Dan B. Allender, "Sentuhan fisik termasuk: Tingkat sangat parah yakni persetubuhan maupun hubungan seksual secara oral atau anal; tingkat parah yakni rangsangan terhadap vagina dengan sentuhan tangan atau penetrasi, membelai dada, atau bentuk apa saja yang menirukan hubungan seksual; tingkat tidak parah yakni ciuman seksual, sentuhan pada dada, pantat, paha, atau alat kelamin yang masih berbusana.. ${ }^{24}$

Jadi pelecehan seksual dengan kontak langsung atau sentuhan fisik adalah menyentuh bagian-bagian intim (paha, pantat, payudara, alat kelamin) dan paksaan untuk melakukan hubungan seks secara oral, vaginal atau anal atau percobaan hubungan seks dan juga sampai kepada perkosaan.

Pelecehan seksual dengan menyentuh atau kontak langsung dengan penyintas (survivor) di antaranya adalah: ${ }^{25}$

(1) Incest merupakan tindak pelecehan seksual yang dilakukan oleh anggota keluarga seperti ayah dan saudara laki-laki atau paman dan

\footnotetext{
${ }^{21}$ Stephen Arterburn dan Jim Burns, Arahkan Dengan Jitu (Yogyakarta: Yayasan ANDI), 155.

${ }^{22}$ Bunga K. Kobong, "Diktat Kuliah Pelayanan Anak Beresiko” (Makassar: STT Jaffray, April 2009), 2.

${ }^{23}$ Daughter: Modul VCD (Philippines: n.p., n.d.), 19.

${ }^{24}$ Dan B. Allender, Hati Yang Luka Kemenangan Atas Derita Pelecehan Seksual (Jakarta: BPK Gunung Mulia, 2001), 33.

${ }^{25}$ Kekerasan Seksual Terhadap Anak: 10 Langkah Perlindungan dan Pendampingan Anak Penyintas Kekerasan Sexual (Jakarta: World Vision International Indonesia dan Sahabat Peduli, 2006), 1.
} 
saudara sepupu atau anggota keluarga jauh dan atau anggota dekat lainnya yang memiliki hubungan darah dengan penyintas, yang tinggal serumah dengannya.

(2) Molestik. Keadaan dimana terjadi pemaksaan dan penyerangan seksual terhadap anak sambil mengancam yang berakhir dengan perkosaan.

(3) Paedofilia. Pemanfaatan dan penikmatan anak melalui hubungan sexual sejenis untuk pemuasan hasrat orang dewasa. Biasanya hubungan ini didahului dengan pengembangan relasi yang akrab dan menciptakan ketergantungan psikologis.

(4) Sodomi. Sering terjadi pada anak laki-laki, di mana terjadi hubungan seksual meniru binatang yaitu melalui dubur (anal) maupun mulut (oral).

(5) Dual masturbasi. Memaksa anak untuk merangsang alat kelamin pelaku sambil ia sendiri melakukan hal yang sama terhadap penyintas.

(6) Exploitasi atau perdagangan seks komersial.

\section{METODOLOGI PENELITIAN}

\section{Keadaan Psikologis Mahasiswa}

Mengingat mahasiswa STT Jaffray datang dari berbagai suku dan daerah dengan latar belakang keluarga masing-masing, maka masalahmasalah psikologis pun banyak ditemui khususnya bagi mereka yang tinggal di dalam asrama. Penyesuaian diri dengan lingkungan asrama dan kebiasaan di rumah, seringkali menimbulkan masalah-masalah psikologis. Masalah-masalah yang dibawa dari daerahnya bertumpuk dengan masalah-masalah yang baru muncul saat mereka ada di asrama pun menambah beban psikologis. Yang lebih parah lagi ada beberapa di antara mereka masih membawa luka lama atau trauma, secara khusus trauma yang dialami akibat pelecehan seksual.

Menurut ibu asrama sekitar dua puluh persen penghuni asrama khususnya asrama putri pernah mengalami pelecehan seksual dengan kontak langsung atau sentuhan di masa kanak-kanak dan sebagian besar pernah mengalami pelecehan seksual tanpa sentuhan. Rupanya masalah psikologis inilah yang menyebabkan adanya fenomena "kerasukan setan" sekitar tiga tahun lalu, di mana beberapa mahasiswa putri suka berteriak-teriak, histeris dan kejang-kejang. Meskipun telah berulang kali diadakan doa pelepasan dari pengaruh kuasa setan tetap saja fenomena itu ada. Ketika diselidiki ternyata mereka yang sering histeris pernah mengalami pelecehan seksual bahkan sampai pada tingkat 
perkosaan. Setelah diketahui lukanya, maka bimbingan yang efektif pun diberikan. Akhirnya fenomena kerasukan setan sudah berkurang bahkan tidak muncul lagi. ${ }^{26}$

Berikut ini pengalaman dari beberapa mahasiswa-mahasiswi STT Jaffray Makassar yang mengalami pelecehan seksual di masa kanakkanak:

Pertama, Kelas III SD Rafflesia (nama samaran) tinggal di kompleks bermain bersama dengan teman-teman lainnya. Pelaku memanggil Rafflesia dan memberinya permen karet. Pelaku membuka bungkusan permen tersebut dan memasukkan kemulut Rafflesia, tetapi pelaku memasukkan mulutnya juga ke mulut Rafflesia. Kelas V SD Rafflesia juga pernah mengalami diperlakukan oleh pelaku yang lain yaitu memeluknya dan meraba-raba bagian intim kewanitaannya. ${ }^{27}$

Kedua, Anggrek (nama samaran) mengalami pelecehan seksual kelas II SD. Setiap papa dan mama pergi pelayanan, pelaku (20 tahun) datang ke rumah untuk menjaga mereka karena mama dan papa sudah percaya dan menganggap pelaku seperti keluarga. Hal tersebut dimanfaatkan oleh pelaku. Pelaku masuk dalam kamar Anggrek, celana dalam Anggrek dibuka oleh pelaku dan pelaku memasukkan jarinya sehingga Anggrek mengalami kesakitan. ${ }^{28}$

Ketiga, Bintang (nama samaran) usia 8 tahun, dari Sekolah Dasar sudah tinggal di panti asuhan. Si pelaku adalah kakak senior (kakak rohani) meraba-raba bagian intim pria saat mandi berdua, hal ini dilakukan oleh pelaku berulang kali. ${ }^{29}$

Keempat, Melati (nama samaran) tidur di lantai dua. Pintu kamar Melati tidak pernah dikunci, karena orang tua melarang anak-anaknya untuk mengunci pintu kamar. Pada malam itu pelaku masuk dalam kamarnya. Melati mulai menyadarinya saat pelaku mulai menyentuh bagian intim wanitanya. ${ }^{30}$

\section{Jenis Penelitian}

Penelitian ini penulis menggunakan penelitian kuantitatif. Penulis melakukan wawancara langsung dengan beberapa mahasiswa dan dosen, serta membagikan beberapa angket pada mahasiswa STT Jaffray.

\section{Populasi}

\footnotetext{
${ }^{26}$ Ivone Palar, Wawancara Oleh Penulis (Makassar: STT Jaffray, 14 April 2013.

${ }^{27}$ Rafflesia, Wawancara Oleh Penulis (Makassar, 28 Mei 2013).

${ }^{28}$ Anggrek, Wawancara Oleh Penulis (Makassar, 28 Mei 2013).

${ }^{29}$ Bintang, Wawancara Oleh Penulis (Makassar, 28 Mei 2013).

${ }^{30}$ Melati, Wawancara Oleh Penulis (Makassar, 31 Mei 2013).
} 
"Populasi ialah semua anggota kelompok unsur tertentu, seperti orang-orang, kejadian-kejadian, atau benda-benda. Dari segi hasil penelitian, populasi ialah kelompok terbesar yang dipakai peneliti agar hasil penelitiannya dianggap berlaku." 31 Populasi penelitian dalam penelitian ini adalah Sekolah Tinggi Theologia Jaffray Makassar. STT Jaffray memiliki kurang lebih 385 Mahasiswa S1 dan 100 Mahasiswa S2/S3; Unsur Pimpinan 8 orang; Dosen Penuh Waktu 17 orang; Dosen Khusus Musik 6 orang; Dosen Paruh Waktu 12 orang; Dosen Pascasarjana dan Doktor 20 orang; Dosen Khusus Pascasarjana MK 12 orang, dan staf karyawan 13 orang.

\section{Sampel}

"Sampel adalah bagian dari jumlah dan karakteristik yang dimiliki oleh populasi." 33 Dalam penelitian penelitian ini penulis mengambil sampel adalah pada mahasiswa STT Jaffray Makassar dan jumlahnya adalah 50 orang.

\section{Teknik Pengumpulan Data}

Menurut Mohammad Nazir, "Pengumpulan data adalah prosedur yang sistematik dan standar untuk memperoleh data yang diperlukan." ${ }^{4}$ Dalam penelitian penelitian ini, penulis menggunakan teknik pengumpulan data melalui angket, wawancara, observasi, dan penelitian buku (library research).

Pertama, Penelitian buku, penulis mengumpulkan data dan informasi melalui buku-buku yang berhubungan dengan penelitian. Kedua, "Wawancara adalah proses memperoleh keterangan untuk tujuan penelitian dengan cara tanya jawab sambil bertatap muka antara si penanya atau pewawancara dengan si penjawab atau responden dengan menggunakan alat yang dinamakan interview guide (panduan wawancara). Wawancara adalah suatu proses pengumpulan data untuk suatu penelitian." 35 Dari wawancara ini penulis memperoleh data tentang kasus pelecehan seksual yang terjadi pada mahasiswa STT Jaffray di masa kanak-kanak. Penulis mewawancarai 5 orang mahasiswa dan 6 orang dosen.

\footnotetext{
${ }^{31}$ Andreas B. Subagyo, Pengantar Riset Kuantitatif dan Kualitatif (Bandung: Kalam Hidup, 2004), 224.

32"Pimpinan dan Staff Dosen STT Jaffray 2012", Year Book (Makassar: Sekolah Tinggi Theologia Jaffray, 2012), 17-18.

${ }^{33}$ Sugiyono, Metode Penelitian Administrasi (Bandung: Alfa Beta, 2008), 91.

${ }^{34}$ Moh. Nazir, Metode Penelitian (Jakarta Timur: Ghalia Indonesia, 1988), 211.

${ }^{35}$ Ibid., 234 .
} 
Ketiga, Angket yaitu berupa "daftar pertanyaan, yang sering disebutkan secara umum dengan nama kuestioner." ${ }^{\text {"36 }}$ Dalam melakukan penelitian dengan menyebarkan angket kepada 50 mahasiswa.

Keempat, Observasi atau pengamatan adalah "Peneliti mengamati (tanpa intervensi) subjek penelitian (tepatnya gejala yang ada pada subjek) dalam suatu situasi dan mencatat hasil pengamatan itu. ${ }^{37}$ Yang diobservasi pada penelitian ini adalah keadaan psikologis si penyintas (mahasiswa STT Jaffray) yang pernah mengalami pelecehan seksual di masa kanak-kanak hingga berakibat pada trauma.

\title{
Teknik Analisa Data
}

Melalui data yang diperoleh oleh penulis maka teknik analisis data yang digunakan adalah penelitian dengan cara kuantitatif yang menggunakan teknik persentase, kemudian disajikan dalam bentuk tabel. Sedangkan hasil data wawancara akan dianalisis secara kualitatif.

Adapun rumus teknik persentase yang digunakan dalam penelitian angket adalah:

$$
\%=\frac{n}{N} \times 100
$$

\author{
Keterangan: ${ }^{38}$ \\ $\%=$ persentase \\ $\mathrm{n}$ = Nilai yang diperoleh (jumlah jawaban responden) \\ $\mathrm{N}=$ Jumlah seluruh nilai
}

\section{ANALISIS DATA DAN HASIL PEMBAHASAN}

Pada pembahasan ini penulis akan mengolah dan menganalisis hasil penelitian yang telah diperoleh melalui angket yang disebarkan kepada 50 orang mahasiswa STT Jaffray dengan cara kuantitatif yaitu menggunakan teknik presentase, yang kemudian disajikan dalam bentuk tabel. Sedangkan hasil data wawancara kepada 5 mahasiswa dan 6 dosen STT Jaffray akan dianalisis secara kualitatif dan disajikan dalam bentuk penelitian.

\footnotetext{
${ }^{36}$ Moh. Nazir, Metode Penelitian (Jakarta Timur: Ghalia Indonesia, 1988), 245.

${ }^{37}$ Andreas B. Subagyo, Pengantar Riset Kuantitatif dan Kualitatif (Bandung:Kalam Hidup, 2004), 227.

${ }^{38}$ Mohammad Ali, Penelitian Kependidikan Prosedur dan Strategi (Bandung:Angkasa, 1985), 184.
} 
Adapun rumus teknik persentase yang digunakan dalam penelitian angket adalah:

Keterangan: $^{39}$

$$
\%=\frac{n}{N} \times 100
$$

$$
\begin{aligned}
& \%=\text { persentase } \\
& \mathrm{n}=\text { Nilai yang diperoleh (jumlah jawaban responden) } \\
& \mathrm{N}=\text { Jumlah seluruh nilai }
\end{aligned}
$$

Adapun angket yang disebarkan oleh penulis kepada 50 orang mahasiswa STT Jaffray, semuanya dikembalikan 100\% oleh responden. Sedangkan wawancara kepada 5 orang mahasiswa dan 6 orang dosen STT Jaffray semuanya berhasil dilakukan.

\section{Analisis Interpretasi Data}

Tabel 1. Subyek Penelitian

\begin{tabular}{|l|l|l|l|}
\hline $\begin{array}{l}\text { Yang Mengalami } \\
\text { Pelecehan Seksual } \\
\text { Secara Langsung }\end{array}$ & $\begin{array}{l}\text { Yang Mengalami } \\
\text { Pelecehan Seksual } \\
\text { Secara Tidak Langsung }\end{array}$ & $\begin{array}{l}\text { Yang Tidak } \\
\text { Mengalami Pelecehan }\end{array}$ & Total \\
\hline 22 & 10 & 18 & 50 \\
atau & atau & atau & atau \\
$44 \%$ & $20 \%$ & $36 \%$ & $100 \%$ \\
\hline
\end{tabular}

Dari 50 angket yang disebarkan secara acak kepada mahasiswa STT Jaffray didapati $22(44 \%)$ responden mengalami pelecehan seksual secara langsung, dan 10 (20\%) responden mengalami pelecehan seksual secara tidak langsung, sedangkan 18 (36\%) responden tidak mengalami pelecehan seksual.

\section{Klasifikasi Dampak Traumatik}

Penulis mengklasifikasi 3 bagian dari angket yang dikembalikan untuk melihat dampak yang dialami baik secara psikologis, perilaku, dan fisik. Terdapat $44 \%$ responden yang mengalami pelecehan seksual secara langsung ternyata mengalami dampak traumatik baik jangka pendek maupun jangka panjang. Sedangkan yang mengalami pelecehan seksual secara tidak langsung $18 \%$ responden mengalami dampak, $2 \%$ responden ragu-ragu. Sedangkan yang $36 \%$ responden yang tidak mengalami dampak traumatik.

\footnotetext{
${ }^{39}$ Mohammad Ali, Penelitian Kependidikan Prosedur dan Strategi (Bandung: Angkasa, 1985), 184.
} 


\section{Pemahaman Tentang Pelecehan Seksual \\ Analisis Terhadap Hasil Penelitian}

Pertanyaan-pertanyaan yang diajukan oleh penulis menyatakan tentang pemahaman pelecehan seksual yang sebenarnya, menyangkut definisi pelecehan seksual dengan kontak langsung atau sentuhan dan pelecehan seksual tanpa kontak langsung atau sentuhan.

Pada pertanyaan pertama tentang pelecehan seksual hanya sebatas pada menyentuh bagian-bagian intim (paha, pantat, payudara, alat kelamin) dan paksaan untuk melakukan hubungan seks (perkosaan), penulis dapati responden yang menjawab ya ada $32 \%$, ragu-ragu $4 \%$, dan tidak $64 \%$. Pada pertanyaan kedua tentang defenisi pelecehan seksual adalah suatu perbuatan yang sengaja dilakukan oleh seseorang atau sekelompok orang terhadap pihak lain yang berkonotasi seksual, baik melalui perkataan langsung maupun lewat media, mempertontonkan alat kelamin, sentuhan, perkosaan yang merendahkan martabat dan harkat orang yang menjadi korban pelecehan, maka responden yang menjawab ya ada $96 \%$, dan $4 \%$ menjawab ragu-ragu. Pada pertanyaan ketiga tentang persetujuan responden apakah pelecehan seksual merupakan tindak kejahatan, maka responden yang memberi jawaban ya $96 \%$, dan jawaban tidak $4 \%$. Pada pertanyaan keempat tentang persetujuan responden mengenai eksploitasi yaitu perdagangan seks komersial termasuk jenis pelecehan seksual, maka responden memberi jawaban ya $82 \%$, ragu-ragu $14 \%$, dan tidak $4 \%$. Pertanyaan kelima berbicara tentang pengetahuan responden mengenai adanya pelecehan seksual tanpa kontak langsung atau sentuhan seperti exhibitionism, pornografi, voyeurism, dan menggunakan bahasa-bahasa komunikasi seksual, seperti yang biasa digunakan di telepon atau internet dengan menghilangkan batasan privasi sehingga si anak dapat melihat atau mendengar perilaku seksual itu, maka ditemukan responden yang menjawab ya ada $80 \%$, menyatakan ragu-ragu $16 \%$, dan tidak $4 \%$. Jadi, dapat disimpulkan bahwa responden sebagian besar sudah memahami definisi dari pelecehan seksual walaupun masih ada yang belum paham, karena ada $4 \%$ responden yang mengatakan bahwa eksploitasi seks tidak termasuk dalam jenis pelecehan seksual.

\section{Jenis-Jenis Pelecehan Seksual Secara Langsung}

\section{Analisa Terhadap Hasil Penelitian}

Pertanyaan-pertanyaan yang diajukan oleh penulis menunjukkan tentang jenis-jenis pelecehan seksual secara langsung yang dialami oleh responden. Pada pertanyaan keenam tentang apakah responden pernah mengalami Incest di masa kanak-kanak yaitu tindak pelecehan seksual yang dilakukan oleh anggota keluarga baik keluarga inti, keluarga dekat 
maupun keluarga jauh lainnya? Maka didapati responden menjawab ya $26 \%$, ragu-ragu $2 \%$, dan tidak $72 \%$. Pada pertanyaan ketujuh tentang apakah responden pernah mengalami pelecehan seksual seperti Molestik (tindakan penyerangan seksual sambil mengancam yang berakhir dengan perkosaan) di masa kanak-kanak? Maka ditemukan responden yang memberi jawaban ya ada $6 \%$, dan tidak $94 \%$. Pada pertanyaan kedelapan tentang apakah responden pernah mengalami pelecehan seksual seperti Sodomi (hubungan seksual melalui dubur) di masa kanak-kanak? Maka didapati responden yang menjawab ya $10 \%$, dan tidak $90 \%$. Pada pertanyaan kesembilan tentang apakah responden pernah mengalami pelecehan seksual seperti Dual Masturbasi (memaksa anak untuk merangsang alat kelamin pelaku sementara pelaku itu melakukan hal yang sama pada orang lain) di masa kanak-kanak? Responden yang menjawab ya $10 \%$, ragu-ragu $8 \%$, dan tidak $82 \%$. Pada pertanyaan kesepuluh tentang apakah responden pernah mengalami pelecehan seksual seperti diraba-raba atau disentuh dengan tidak pantas bagian organ intim Anda (paha, pantat, payudara dan alat kelamin) di masa kanakkanak? Maka responden yang memberi jawaban ya $34 \%$, yang ragu-ragu $10 \%$, dan yang tidak $56 \%$. Pada pertanyaan kesebelas mengenai apakah responden pernah mengalami Paedofilia yaitu pemanfaatan dan penikmatan anak melalui hubungan seksual demi pemuasan hasrat orang dewasa. Yang menjawab ya $8 \%$, ragu-ragu $6 \%$, dan tidak $86 \%$. Jadi, penulis menganalisa bahwa jenis pelecehan seksual seperti incest, molestik, sodomi, dual masturbasi, diraba-raba atau disentuh dengan tidak pantas pada bagian organ intim (paha, pantat, payudara dan alat kelamin), dan paedofilia pernah dialami oleh mahasiswa STT Jaffray di masa kanakkanak.

\section{Jenis-Jenis Pelecehan Seksual Secara Tidak Langsung}

\section{Analisa Terhadap Hasil Penelitian}

Pertanyaan-pertanyaan yang diajukan oleh penulis menunjukkan tentang jenis-jenis pelecehan seksual secara tidak langsung atau tanpa sentuhan yang dialami oleh responden.

Pada pertanyaan keduabelas, "Apakah Anda pernah mengalami pelecehan seksual tanpa sentuhan seperti perkataan dari seseorang kepada Anda di masa kanak-kanak yang tidak senonoh (jorok, cabul, porno)?" Maka responden yang menjawab ya $62 \%$, ragu-ragu $10 \%$, dan tidak $28 \%$. Pada pertanyaan ketigabelas, "Apakah Anda pernah mengalami exhibitionism di masa kanak-kanak?" Maka responden yang menjawab ya $40 \%$, raguragu $10 \%$, dan tidak 50 \%. Pada pertanyaan keempatbelas, "Apakah Anda pernah mengalami Voyeurism di masa kanak-kanak?" Maka yang menjawab ya $20 \%$, ragu-ragu $10 \%$, dan tidak $70 \%$. Pada pertanyaan 
kelimabelas, "Apakah Anda pernah oleh seseorang diperlihatkan gambargambar porno yang merangsang fantasi seksual Anda di masa kanakkanak?" Responden yang menjawab ya $30 \%$, ragu-ragu $16 \%$, dan tidak $54 \%$. Pada pertanyaan keenambelas, "Apakah pelaku tindakan pelecehan seksual tersebut kebanyakan adalah orang-orang yang dekat dengan Anda atau orang yang Anda kenal?" Responden yang menjawab ya $34 \%$, ragu-ragu $26 \%$, dan tidak $40 \%$. Jadi, analisa penulis terhadap jenis pelecehan seksual tidak langsung seperti perkataan yang tidak senonoh (jorok, cabul, porno), exhibitionism, voyeurism, dan diperlihatkan gambar-gambar porno di masa kanak-kanak juga pernah dialami mahasiswa STT Jaffray.

\section{Dampak Traumatik Bagi Penyintas Pelecehan Seksual Analisa Terhadap Hasil Penelitian}

Pertanyaan-pertanyaan yang diajukan oleh penulis menunjukkan tentang dampak traumatik bagi penyintas pelecehan seksual, baik dampak jangka pendek maupun jangka panjang.

Pada pertanyaan ketujuhbelas, "Apakah peristiwa pelecehan seksual yang Anda alami di masa kanak-kanak itu tidak bisa Anda lupakan sampai saat ini?" Responden yang memberi jawaban ya ada $38 \%$, ragu-ragu $16 \%$, dan tidak $46 \%$. Pada pertanyaan kedelapanbelas, "Apakah Anda mengalami Post Traumatic Stress Disorder (PTSD), yang cirinya adalah bila teringat kembali pada peristiwa tersebut Anda merasa terancam, panik, takut yang luar biasa, dan tidak berdaya, kadang-kadang histeris?" Responden yang menjawab ya ada $16 \%$, ragu-ragu $18 \%$, dan tidak $66 \%$. Pada pertanyaan kesembilanbelas, "Apakah Anda merasakan trauma kembali melalui mimpi, kilas balik, kenangan yang instruktif, atau merasa cemas di dalam situasi yang mengingatkan Anda kepada peristiwa itu?" Responden yang memberi jawaban ya $18 \%$, ragu-ragu $22 \%$, dan tidak 60 $\%$. Pada pertanyaan keduapuluh, "Apakah dampak pelecehan seksual yang dialami anak-anak akan mendatangkan trauma baik jangka pendek maupun jangka panjang?" Responden yang menjawab ya $76 \%$, ragu-ragu $14 \%$, dan tidak $10 \%$.

Jadi, analisa penulis terhadap dampak traumatik bagi penyintas pada tabel 4 adalah bahwa peristiwa pelecehan seksual yang dialami mahasiswa STT Jaffray di masa kanak-kanak belum bisa dilupakan sampai saat ini. Ini artinya bagi mahasiswa STT Jaffray yang mengalami pelecehan seksual di masa kanak-kanak mendatangkan pengalaman traumatik jangka panjang. 


\section{Gangguan Traumatik Bagi Penyintas \\ Analisa Terhadap Hasil Penelitian}

Gangguan traumatik bagi penyintas yang terbagi atas 3 bagian yaitu gangguan traumatik secara psikologis, secara perilaku, dan secara fisik. Pertanyaan nomor duapuluh satu sampai duapuluh delapan berisi tentang gangguan traumatik secara psikologis yang dialami oleh responden yang pernah mengalami pelecehan seksual di masa kanakkanak.

Pada pertanyaan nomor dua puluh satu, "Apakah gejala ini ada pada Anda saat mengalami pelecehan seksual, seperti muncul rasa takut yang berlebihan atau kecemasan?" Responden yang menjawab ya $32 \%$, raguragu $22 \%$, dan tidak $46 \%$. Pada pertanyaan nomor duapuluh dua, "Apakah Anda juga menjadi sulit berkonsentrasi, kurang minat belajar dan turun prestasi?" Maka responden yang menjawab ya $26 \%$, ragu-ragu $26 \%$, dan tidak $48 \%$. Pada pertanyaan nomor duapuluh tiga, "Apakah Anda juga mengalami stress berat, merasa tidak berharga bahkan sampai depresi?", Maka responden yang menjawab ya $18 \%$, ragu-ragu $16 \%$, dan tidak 66 $\%$. Pada pertanyaan nomor duapuluh empat, "Apakah Anda juga mengalami gejala-gejala seperti: sukar tidur, lekas marah, merasakan kemarahan meluap-luap?" Maka responden yang menjawab ya $18 \%$, ragu-ragu $30 \%$, dan tidak $52 \%$.

Pada pertanyaan nomor duapuluh lima "Apakah setelah peristiwa pelecehan seksual tersebut Anda merasa diteror dan gelisah; malu, merasa bersalah, dan membenci diri sendiri; merasa terpisah dari tubuh sendiri?" Maka, responden yang menjawab ya $32 \%$, ragu-ragu $12 \%$, dan tidak 56 \%. Pertanyaan nomor duapuluh enam, "Apakah hari-hari ke depan Anda dilalui dengan penuh duka, perasaan hati yang terluka, hancur, dan kesepian akibat pelecehan seksual tersebut?" Responden menjawab ya $18 \%$, ragu-ragu $14 \%$, dan tidak $68 \%$. Pada pertanyaan nomor duapuluh tujuh, "Apakah Anda menunjukkan emosi yang kaku dan kekurangan minat terhadap orang lain dan dunia atau menganggap peristiwa pelecahan seksual tersebut tidak terjadi (penyangkalan)?" Maka responden yang menjawab ya $10 \%$, ragu-ragu $38 \%$, dan tidak $52 \%$. Pertanyaan nomor duapuluh delapan, "Apakah setelah peristiwa pelecehan seksual tersebut Anda merasa: tidak mudah percaya kepada orang lain; mengisolasi diri dari orang-orang maupun aktivitas-aktivitas?" Responden yang memberi jawaban ya ada $16 \%$, yang memberi jawaban ragu-ragu $28 \%$, dan yang menjawab tidak ada $56 \%$. Dari delapan pertanyaan yang diajukan untuk melihat apakah ada gangguan traumatik secara psikologis bagi penyintas, maka ditemukan bahwa ada terdapat dalam kehidupan mahasiswa yang mengalami pelecehan seksual di masa kanak-kanak. 
Pertanyaan nomor duapuluh sembilan sampai dengan tigapuluh lima untuk meneliti apakah gangguan traumatik secara perilaku dialami oleh penyintas yang mengalami pelecehan seksual di masa kanak-kanak.

Pada pertanyaan nomor duapuluh sembilan, "Apakah Anda mengalami gangguan perilaku seperti mempertanyakan seksualitas dan jenis kelamin Anda (cenderung menjadi homoseks)?" Maka yang menjawab ya $4 \%$, ragu-ragu $12 \%$, dan tidak $84 \%$. Pada pertanyaan nomor tigapuluh, "Apakah untuk melupakan peristiwa tersebut Anda menjadi pengguna atau pecandu obat-obat terlarang dan minuman beralkohol, perokok?" Maka yang menjawab ya $4 \%$, ragu-ragu $8 \%$, dan tidak $88 \%$.

Pertanyaan nomor tigapuluh satu, "Apakah perilaku Anda berubah menjadi liar, susah diatur, pemberontak, hiperaktif atau malah menjadi pendiam dan tidak suka bergaul, acuh tak acuh?" Yang menjawab ya 16 $\%$, ragu-ragu $8 \%$, dan tidak $76 \%$. Pertanyaan nomor tigapuluh dua, "Apakah Anda pernah mengalami penyimpangan pola mental dan ingin bunuh diri?" Responden yang memberi jawaban ya $6 \%$, ragu-ragu $8 \%$, dan yang menjawab tidak $86 \%$. Pertanyaan nomor tigapuluh tiga, "Apakah Anda cenderung ingin balas dendam dan menjadi pelaku pelecehan seksual?" Maka didapati responden yang menjawab ragu-ragu $12 \%$, dan tidak 88 $\%$ dan $0 \%$ untuk jawaban ya. Pertanyaan nomor tigapuluh empat, "Apakah Anda menjadi terobsesi dengan seks atau sama sekali tidak mau melakukan hubungan seksual (dingin terhadap lawan jenis)?" Responden yang menjawab ya $10 \%$, ragu-ragu $22 \%$, dan tidak $68 \%$. Pertanyaan nomor tigapuluh lima, "Apakah Anda mengalami krisis adaptasi dimana Anda sendiri mulai merangsang diri sendiri atau sering masturbasi?" Responden yang menjawab ya $14 \%$, ragu-ragu $18 \%$, dan tidak $68 \%$.

Analisa penulis menemukan bahwa rata-rata mahasiswa mengalami gangguan traumatik secara perilaku, namun tidak didapati adanya keinginan untuk balas dendam maupun menjadi pelaku pelecehan seksual walaupun ada $12 \%$ yang ragu-ragu mengalami gejala tersebut. Namun dari hasil wawancara langsung antara penulis dengan beberapa mahasiswa yang mengalami pelecehan tersebut, mereka mengatakan benci kepada pelaku, dendam dan ingin membunuhnya. Melati (nama samaran) mengatakan bahwa ia berubah menjadi ketus, bicara dengan pelaku kasar, benci pada pelaku, tertutup, tidak ramah, keras, tidak gampang percaya pada laki-laki, memiliki tekad harus jadi orang. ${ }^{40}$ Mawar (nama samaran) juga mengatakan bahwa ia takut, benci, marah, dendam, hidup dalam ketakutan dan kebencian. ${ }^{41}$ Hal yang sama

\footnotetext{
${ }^{40}$ Melati, Wawancara Oleh Penulis (Makassar, 31 Mei 2013).

${ }^{41}$ Mawar, Wawancara Oleh Penulis (Makassar, 28 Mei 2013).
} 
juga dirasakan oleh Anggrek bahwa gangguan traumatik yang dialaminya adalah takut pada om-om atau kakek-kakek, dendam, benci, emosi, sama sekali tidak mau bertemu dengan pelaku, rasanya mau membunuhnya. ${ }^{42}$

Pertanyaan-pertanyaan pada nomor tigapuluh enam sampai empatpuluh satu untuk mengetahui sejauh mana penyintas mengalami gangguan traumatik secara fisik.

Pada pertanyaan nomor tigapuluh enam, "Apakah Anda mengalami gangguan fisik akibat pelecehan seksual tersebut seperti kesulitan dalam berjalan atau duduk?" Responden yang memberi jawaban ya $2 \%$, raguragu $4 \%$, dan tidak $94 \%$. Pada pertanyaan nomor tigapuluh tujuh, "Apakah Anda mengalami gangguan fisik akibat pelecehan seksual tersebut seperti bau yang tidak biasa atau pendarahan pada vagina?" Responden yang menjawab ya $4 \%$, dan tidak $96 \%$. Pada pertanyaan nomor tigapuluh delapan, "Apakah Anda mengalami infeksi pada saluran kemih dan daerah di bagian bawah perut akibat pelecehan seksual tersebut?" Maka ditemukan responden yang menjawab ya $2 \%$, ragu-ragu $6 \%$, dan tidak $92 \%$. Pada pertanyaan nomor tigapuluh sembilan, "Apakah Anda mengalami gangguan fisik akibat pelecehan seksual tersebut seperti memar atau luka pada alat kelamin dan mulut atau dubur?" Maka responden menjawab ya $4 \%$, dan tidak $96 \%$. Pada pertanyaan nomor empatpuluh, "Apakah Anda mengalami gangguan fisik akibat pelecehan seksual tersebut seperti IMS (Infeksi Menular Seksual)?" Responden yang menjawab ragu-ragu $4 \%$, dan tidak $96 \%$. Pada pertanyaan nomor empatpuluh satu, "Apakah Anda mengalami gangguan fisik akibat pelecehan seksual tersebut seperti kehamilan pada usia dini?" Responden yang menjawab ragu-ragu $2 \%$, dan tidak $98 \%$.

Jadi, analisa penulis terhadap gangguan traumatik secara fisik adalah tidak ada mahasiswa yang mengalami IMS (Infeksi Menular Seksual) dan juga tidak ada yang mengalami kehamilan pada usia dini, walaupun ada $2 \%$ yang ragu-ragu apakah pernah mengalaminya. Sedangkan untuk gangguan secara fisik yang lainnya ada yang mengalami walaupun persentasenya kecil.

\section{Proses Pemulihan Traumatik}

\section{Analisa Terhadap Hasil Penelitian}

Pertanyaan yang diajukan oleh penulis menunjukkan tentang proses pemulihan traumatik dan langkah-langkah untuk menolong penyintas mengatasi traumatik tersebut.

\footnotetext{
${ }^{42}$ Anggrek, Wawancara Oleh Penulis (Makassar, 28 Mei 2013).
} 
Pada pertanyaan nomor empatpuluh dua, "Apakah pada saat Anda mengalami pelecehan seksual tersebut, Anda langsung atau beberapa hari kemudian menceritakan peristiwa tersebut kepada seseorang yang Anda kenal?" Responden yang menjawab ya $20 \%$, ragu-ragu $14 \%$, dan tidak $66 \%$. Pada pertanyaan nomor empatpuluh tiga, "Bila Anda tidak menceritakan peristiwa tersebut langsung kepada seseorang, apakah karena Anda merasa takut, malu atau orang itu tidak akan percaya dengan apa yang Anda akan ceritakan?" Maka responden yang menjawab ya $36 \%$, ragu-ragu $24 \%$, dan tidak $40 \%$. Pada pertanyaan nomor empatpuluh empat, "Apakah Anda terbuka menceritakan peristiwa tersebut kepada seseorang setelah Anda beranjak dewasa?" Responden yang menjawab ya $50 \%$, ragu-ragu $12 \%$, dan tidak $38 \%$. Pada pertanyaan nomor empatpuluh lima, "Apakah Anda merasa bahwa peristiwa pelecehan seksual yang dialami itu adalah kesalahan Anda?" Responden yang memberi jawaban ya $16 \%$, ragu-ragu $26 \%$, dan tidak $58 \%$. Pada pertanyaan nomor empatpuluh enam, "Apakah ada seseorang yang mengatakan kepada Anda dengan penegasan berulang kali bahwa "apa yang telah terjadi bukanlah kesalahanmu"? Responden yang menjawab ya $38 \%$, ragu-ragu $22 \%$, dan tidak $40 \%$. Pada pertanyaan nomor empatpuluh tujuh, Apakah Anda mendapat pelayanan medis saat mengalami gangguan fisik akibat pelecehan seksual tersebut?" Responden yang memberi jawaban ya $2 \%$, ragu-ragu $12 \%$, dan tidak $86 \%$. Pada pertanyaan nomor empatpuluh delapan, "Apakah Anda mendapat pelayanan konseling saat mengalami gangguan psikologis dan perilaku akibat pelecehan seksual tersebut?" 16\% menjawab ya, $4 \%$ menjawab ragu-ragu, dan $80 \%$ menjawab tidak. Pada pertanyaan nomor empatpuluh sembilan, "Apakah Anda mendapat pelayanan pastoral saat mengalami gangguan psikologis dan perilaku akibat pelecehan seksual tersebut?" Maka ditemukan bahwa responden yang menjawab ya $12 \%$, ragu-ragu $6 \%$, dan tidak $82 \%$. Pertanyaan nomor limapuluh, "Apakah Anda mendapat pelayanan hukum atau advokasi (pendampingan) saat diperlukan setelah peristiwa pelecehan seksual tersebut?" Responden yang menjawab ya $6 \%$, raguragu $8 \%$, dan tidak $86 \%$. Pada pertanyaan nomor limapuluh satu, Apakah Anda yakin telah mengalami pemulihan akibat pelecehan seksual di masa kanak-kanak Anda tersebut?" Maka $60 \%$ responden menjawab ya, $24 \%$ ragu-ragu, dan $16 \%$ menjawab tidak.

Pada pertanyaan nomor limapuluh dua, "Apakah pemulihan traumatik dari peristiwa pelecehan seksual itu memerlukan proses/waktu?" Maka responden yang menjawab ya $78 \%$, ragu-ragu $10 \%$, dan tidak $12 \%$. Pertanyaan nomor limapuluh tiga, "Apakah Anda setuju bahwa pemulihan traumatik akibat pelecehan seksual tersebut di atas perlu kerja sama 
semua pihak dan diberi pelayanan secara holistik: baik dari segi pelayanan medis, pelayanan konseling, pelayanan pastoral dan juga pelayanan hukum?" Responden yang menjawab ya $90 \%$, ragu-ragu $4 \%$, dan tidak $6 \%$.

Jadi, analisa terhadap proses pemulihan traumatik menyatakan bahwa mahasiswa yang mengalami pelecehan seksual di masa kanakkanak lebih banyak tidak menceritakan peristiwa tersebut kepada orang yang dikenal karena merasa malu, takut atau orang itu tidak percaya pada ceritanya. Namun setelah dewasa mahasiswa terbuka untuk menceritakan peristiwa tersebut. Kebanyakan mahasiswa mengetahui bahwa yang terjadi bukanlah kesalahannya dan untuk mengalami pemulihan akibat pelecehan seksual membutuhkan proses atau waktu. Ada 90 \% mahasiswa menyetujui bahwa untuk mengalami pemulihan dari masa traumatik akibat pelecehan seksual di masa kanak-kanak diperlukan kerja sama semua pihak dan diberi pelayanan secara holistik baik dari segi pelayanan medis, pelayanan konseling, pelayanan pastoral, dan juga pelayanan hukum atau advokasi (pendampingan).

\section{Kesimpulan Analisis}

Setelah menganalisis dan menginterpretasi data pada setiap tabel, maka selanjutnya penulis akan menyimpulkannya sehubungan dengan pemulihan traumatik terhadap penyintas yang mengalami pelecehan seksual di masa kanak-kanak:

Pertama, Belum semua mahasiswa mengerti atau memahami tentang pengertian pelecehan seksual yang sebenarnya. (1) Oleh sebab itu, perlu bagi mahasiswa untuk diberi pengetahuan tentang pelecehan seksual. (2) Juga orang tua mengantisipasi supaya tidak terjadi pelecehan seksual dengan memberikan pemahaman tentang pelecehan seksual kepada anak-anaknya. Sebagaimana yang dikatakan oleh Anggrek (nama samaran) mahasiswa STT Jaffray yang pernah mengalami pelecehan seksual di masa kanak-kanak. Dia mengatakan, "Anak-anak harus diberitahukan mana yang boleh dipegang dan tidak boleh dipegang karena anak kecil tidak tau apa-apa, bila diberitahu anak bisa antisipasi atau jaga diri. Dari kecil orang tua harus beritahukan pada anak. ${ }^{43}$ (3) Orang tua harus menjamin keamanan dalam rumah. Sebagaimana yang dikatakan oleh Melati (nama samaran), "Orang tua harus menjamin betul keamanan dalam rumah, jangan terlalu banyak, dan jangan terlalu lama orang menginap di rumah, atau menitipkan anak-anak untuk dijaga oleh keluarga dekat maupun kenalan dekat ketika orang tua tidak ada di rumah. ${ }^{44}$

\footnotetext{
${ }^{43}$ Anggrek, Wawancara Oleh Penulis (Makassar, 28 Mei 2013).

${ }^{44}$ Melati, Wawancara Oleh Penulis (Makassar, 31 Mei 2013).
} 
Kedua, Semua jenis pelecehan seksual baik secara langsung maupun secara tidak langsung di masa kanak-kanak pernah dialami oleh mahasiswa STT Jaffray. Peristiwa tersebut bukan hanya terjadi satu kali saja tapi berulang kali, dan pelakunya kebanyakan adalah orang-orang yang dekat atau orang-orang yang dikenalnya.

Ketiga, Mahasiswa yang pernah mengalami pelecehan seksual di masa kanak-kanak mengalami gangguan traumatik baik jangka pendek maupun jangka panjang, seperti: gangguan secara psikologis, gangguan secara perilaku dan gangguan traumatik secara fisik. Wawancara penulis dengan Melati (nama samaran) dikatakan bahwa gangguan traumatik secara fisik yang dialaminya adalah kesakitan di bagian vagina selama seminggu. ${ }^{45}$ Pdt. Ivan Weismann mengatakan, "Takut, gelisah, rendah diri, tidak percaya kepada orang lain, perasaan negatif, dan tidak lagi produktif." ${ }^{4}$ Peniel Maiaweng juga mengatakan, "Ketakutan terhadap lawan jenis, kebencian, bisa juga menjadi agresif secara seksual." 47 Menurut Simon Tarigan, bahwa gangguan traumatik yang dialami bagi seseorang yang mengalami pelecehan seksual adalah trauma dengan semua kegiatan seksual. Jika sudah menikah mengalami ketakutan. Bisa menjadi kasar. Bisa menjadi orang yang kurang percaya diri, takut pada laki-laki, pengalaman-pengalaman membuat dia menjadi takut. ${ }^{48}$

Keempat, kebanyakan mahasiswa STT Jaffray yang mengalami pelecehan seksual dengan kontak langsung belum pulih dari dampak traumatiknya, khususnya dampak traumatik secara psikologis.

Kelima, Langkah-langkah komprehensif dan pelayanan holistik sangat diperlukan bagi pemulihan traumatik terhadap mereka yang mengalami pelecehan seksual: 1) Langkah awal untuk pemulihan adalah mahasiswa tersebut harus bersikap terbuka, jangan menutup diri tapi menceritakan peristiwa tersebut agar ia dapat mengidentifikasi luka yang dialaminya. Ibu Meily Lunanta K. mengatakan, "STT Jaffray siap untuk menolong tapi tidak ada mahasiswa yang datang untuk terbuka, dan dalam kelas belum sepenuhnya terbuka. ${ }^{49}$ Senada dengan itu Simon Tarigan, juga mengatakan, "Belajar untuk orang-orang itu untuk berani terbuka, karena kadang-kadang mereka tertutup. ${ }^{50}$ 2) Orang tua harus memberi dukungan kepada anaknya dan jangan menyalahkannya. Wawancara penulis dengan dosen mengenai apa yang orang tua harus

\footnotetext{
${ }^{45}$ Melati, Wawancara Oleh Penulis (Makassar, 31 Mei 2013).

${ }^{46}$ Ivan Weismann, Wawancara Oleh Penulis (Makassar, 30 Mei 2013).

${ }^{47}$ Peniel C. D. Maiaweng, Wawancara Oleh Penulis (Makassar, 30 Mei 2013).

${ }^{48}$ Simon Tarigan, Wawancara Oleh Penulis (Makassar, 31 Mei 2013).

${ }^{49}$ Meily Lunanta K., Wawancara Oleh Penulis (Makassar, 28 Mei 2013).

${ }^{50}$ Simon Tarigan, Wawancara Oleh Penulis (Makassar, 31 Mei 2013).
} 
lakukan untuk menolong anak yang traumatik akibat pelecehan seksual adalah sebagai berikut: Ivan Weismann, mengatakan, "Mengasihi dan menerima keadaannya, memberikan perhatian dalam waktu bersama, mengerjakan kegiatan bersama, dan rekreasi bersama." ${ }^{51}$ Peniel C. D. Maiaweng juga mengatakan, "Seorang ibu harus memfungsikan perannya sebagai seorang wanita terhadap anak perempuannya jika yang mengalami adalah anak perempuan untuk pemulihan jati diri kewanitaannya, begitu juga sebaliknya untuk anak laki-laki." ${ }^{52}$ Menurut Simon Tarigan, "Orang tua tidak punya pengetahuan tentang pelecehan seksual perlu mendatangi orang-orang yang pakar di bidang pelecehan seksual. Mendampingi anak ini dan menerima dia sebagaimana dia adanya, jangan membuangnya, bimbing, dan damping." ${ }^{53}$ 3) Gereja turut serta dalam memberikan pelayanan pastoral bagi mereka yang mengalami pelecehan seksual. Penting sekali peran serta dari semua kerabat, baik itu hamba-hamba Tuhan, aktivis gereja, guru Sekolah Minggu, dan yang lainnya untuk turut menolong penyintas yang mengalami traumatik akibat pelecehan seksual. Seperti yang dikatakan oleh Anggrek (nama samaran) bahwa gereja harus merangkul mereka, jangan menghakimi, dan jangan mengucilkan mereka. ${ }^{54}$ Melati (nama samaran) juga mengungkapkan bahwa gereja harus mau menjadi telinga untuk mendengar, hamba Tuhan yang harus siap dan tampil untuk berbagi, orang ini mau menjamin menjaga rahasia dan jangan dijadikan ilustrasi khotbah kecuali ada minta izin. ${ }^{55}$ Peniel C. D. Maiaweng yaitu penerimaan dan penghargaan melalui kepercayaan pelayanan yang diberikan kepadanya. ${ }^{36}$ Hal yang sama juga dikatakan oleh. Ivan Weismann berupa konseling, untuk melibatkan pelayanan kadangkadang agak sulit tapi harus ada upaya bagaimana pada akhirnya dia terlibat. Ada tahap-tahap atau proses, prosesnya adakan perkunjungan, dalam perkunjungan mengajak ikut hadir dalam kegiatan pada akhirnya terlibat. ${ }^{57}$

Menurut Simon Tarigan, "Gereja mengundang pakar-pakar dalam ibadah-ibadah pemuda menjadi sesuatu topik yang dibahas bagaimana mencegah, menangani, menerima orang-orang seperti ini, jangan dikucilkan. ${ }^{58}$ Yang dikatakan Sarce Riah Hana adalah ada pelayanan khusus untuk mengatasi emosi yang terluka, ada psikiater yaitu kerja

\footnotetext{
${ }^{51}$ Ivan Weismann, Wawancara Oleh Penulis (Makassar, 30 Mei 2013).

${ }^{52}$ Peniel C. D. Maiaweng, Wawancara Oleh Penulis (Makassar, 30 Mei 2013).

${ }^{53}$ Simon Tarigan, Wawancara Oleh Penulis (Makassar, 31 Mei 2013).

${ }^{54}$ Anggrek, Wawancara Oleh Penulis (Makassar, 28 Mei 2013).

${ }^{55}$ Melati, Wawancara Oleh Penulis (Makassar, 31 Mei 2013).

${ }^{56}$ Peniel C. D. Maiaweng, Wawancara Oleh Penulis (Makassar, 30 Mei 2013).

${ }^{57}$ Ivan Weismann, Wawancara Oleh Penulis (Makassar, 30 Mei 2013).

${ }^{58}$ Simon Tarigan, Wawancara Oleh Penulis (Makassar, 31 Mei 2013).
} 
sama psikologi umum dan psikologi Kristen, yang paling penting ada pelayanan anak dan remaja. Melayani anak itu bukan asal-asalan karena itu adalah tiang gereja. ${ }^{59}$

Keenam, STT Jaffray perlu memberikan sistem pendampingan bagi mahasiswa yang mengalami pelecehan seksual di masa kanak-kanak agar mengalami pemulihan. Adapun sistem pendampingan atau advokasi yang dapat diberikan adalah berikut ini:

1. Mengoptimalkan pelayanan konseling.

Perlu bagi mahasiswa dibimbing untuk mengalami pemulihan, sehingga selesai dari STT Jaffray dapat melayani secara efekif. Sebab tidak menutup kemungkinan di tempat pelayanannya juga mereka akan menemukan orang-orang yang mengalami pelecehan seksual. Wawancara penulis dengan Melati (nama samaran) mengatakan kepahitan harus diselesaikan pada saat masuk STT Jaffray. ${ }^{60}$ Demikian juga wawancara penulis dengan beberapa dosen, menurut Peniel C. D. Maiaweng yaitu membimbing secara psikologis dan pembinaan mental melalui terapi jiwa yang dilaksanakan oleh konselor yang memiliki sesama jenis kelamin. ${ }^{6 P}$ Hal yang sama juga dikatakan oleh Ivan Weismann, yaitu dikonseling ada pertobatan. Dari konseling memberi dia pengampunan, lalu memberikan bimbingan supaya dia dapat melaksanakan tugas dan tanggung jawabnya sebagai mahasiswa. ${ }^{62}$

Oleh sebab itu, perlu adanya ibu dan bapak asrama yang fokus dan peka menangani para mahasiswa. Ibu dan bapak asrama yang mana sebagai konselor bagi mahasiswanya. Demikian juga perlu ruangan konseling diefektifkan guna mengkonseling para mahasiswa. Sambil kuliah harus ada yang dimentoring, bukan hanya kuliah. Memaksimalkan peranan konseling di STT Jaffray untuk menolong penyintas keluar dari traumatiknya yaitu menyediakan konselor dan tempat untuk konselor, dari konselor harus bisa dipercaya tidak cerita pada orang sehingga bisa diterima oleh korban. Konseling secara berkelompok punya masalah yang sama. ${ }^{63}$

2. Membentuk Kelompok-Kelompok Kecil

Mawar (nama samaran) memberikan jawaban yaitu dengan membuat seminar dan bimbingan, tentunya dosen yang bisa dipercaya atau yang bisa menyimpan rahasia. ${ }^{64}$ Anggrek (nama samaran),

\footnotetext{
${ }^{59}$ Sarce Riah Hana, Wawancara Oleh Penulis (Makassar, 31 Mei 2013).

${ }^{60}$ Melati, Wawancara Oleh Penulis (Makassar, 31 Mei 2013).

${ }^{61}$ Peniel C. D. Maiaweng, Wawancara Oleh Penulis (Makassar, 30 Mei 2013).

${ }^{62}$ Ivan Weismann, Wawancara Oleh Penulis (Makassar, 30 Mei 2013).

${ }^{63}$ Ivan Weismann, Wawancara Oleh Penulis (Makassar, 30 Mei 2013).

${ }^{64}$ Mawar, Wawancara Oleh Penulis (Makassar, 28 Mei 2013).
} 
membuat satu forum sesama jenis, kumpulkan mahasiswa yang pernah mengalami pelecehan seksual sehingga tidak ada rasa malu untuk cerita pada akhirnya mahasiswa itu bisa percaya dan pulih dari trauma. ${ }^{65}$ Sarce Rien Hana mengemukakan bahwa sebaiknya sepuluh mahasiswi STT Jaffray punya satu bapak/ibu rohani (bisa dosen, bisa istri dosen) begitu juga sebaliknya. Bapak/ibu rohani harus dapat dipercaya, punya integritas sehingga orang bisa berbagi kepadanya. Bapak/Ibu asrama tidak bisa merangkul mahasiswa yang begitu banyaknya. ${ }^{66}$ Hal senada dikatakan oleh Rafflesia (samaran):

Apa yang STT Jaffray dapat lakukan bagi mahasiswanya yang di masa kanak-kanak mengalami pelecehan seksual dan belum mengalami pemulihan yaitu jangkau mahasiswa, merangkulnya, sharing dengan syarat setiap dosen membimbing satu mahasiswa dan bisa menjaga rahasia. Saat pendaftaran atau ospek dilaksanakan dosen tanya pada mahasiswa baru tentang masa lalunya. Dosen diharapkan mampu untuk menggali kepribadian mahasiswa baru mencari tahu sampai sedalam-dalamnya tentang masa lalunya. Dari mahasiswa baru sampai selesai harus dimentori oleh dosen. ${ }^{67}$

Jadi pemulihan traumatik bagi mahasiswa STT Jaffray yang pernah mengalami pelecehan seksual di masa kanak-kanak dapat dilakukan dengan pelayanan yang komprehensif, yaitu bekerja sama dengan orang tua penyintas, mengoptimalkan pelayanan konseling dan membentuk kelompok-kelompok kecil yang integritas.

\footnotetext{
${ }^{65}$ Anggrek, Wawancara Oleh Penulis (Makassar, 28 Mei 2013).

${ }^{66}$ Sarce Riah Hana, Wawancara Oleh Penulis (Makassar, 31 Mei 2013).

${ }^{67}$ Rafflesia, Wawancara Oleh Penulis (Makassar, 28 Mei 2013).
} 


\section{PENUTUP}

\section{Kesimpulan}

Pertama, dampak negatif yang dialami anak-anak akibat pelecehan seksual akan mendatangkan trauma jangka panjang yang disebut juga Post Traumatic Stress Disorder (PTSD) atau Penyimpangan Jiwa Akibat Tekanan Traumatik (PJATT).

Kedua, salah satu pintu pemulihan adalah dengan mengetahui apa pokok permasalahannya, serta adanya keterbukaan, dan melibatkan Allah dalam proses tersebut, karena itu semua harus mengambil bagian dalam proses pemulihan tersebut.

Ketiga, Dalam proses pengobatan dan pemulihan, maka harus dilakukan dengan cara pelayanan holistik seperti, pelayanan medis, pelayanan psikologis, pelayanan hukum atau advokasi (pendampingan), dan pelayanan rohani.

\section{KEPUSTAKAAN}

\section{Alkitab}

Alkitab. Jakarta: Lembaga Alkitab Indonesia, 2007.

Kamus

Kamus Besar Bahasa Indonesia. Jakarta: Balai Pustaka, 2005

Buku-Buku

Ali, Mohammad. Penelitian Kependidikan Prosedur dan Strategi. Bandung: Angkasa, 1985.

Allender, Dan B. Hati Yang Luka Kemenangan Atas Derita Pelecehan Seksual. Jakarta: BPK Gunung Mulia, 2001.

Budiardjo, Tri. Pelayanan Anak Yang Holistik. Yogyakarta: ANDI, 2011.

Hesti, Konseling Dan Terapi Dengan Anak Dan Orang Tua. Jakarta: Gravindo, n.d.

Hill, Margaret et al. Menyembuhkan Luka Batin Akibat Trauma. Jakarta: Kartidaya dan Yogyakarta: Gloria Graffa, 2006.

Kementerian Pemberdayaan Perempuan dan Perlindungan Anak Republik Indonesia. 2011. 
Langberg, Diane. Di Ambang Pintu Pengharapan. Jakarta:BPK Gunung Mulia, 2008.

McGee, Robert S. Pemulihan Gambar Diri. Jakarta:Metanoia, 1998.

Nazir, Moh. Metode Penelitian. Jakarta Timur:Ghalia Indonesia, 1988.

Piper, John dan Justin Taylor, Seks dan Supremasi Kristus. Surabaya: Momentum, 2008.

Subagyo, Andreas B. Pengantar Riset Kuantitatif dan Kualitatif. Bandung: Kalam Hidup, 2004.

Sugiyono. Metode Penelitian Administrasi. Bandung: Alfa Beta, 2008.

Toha, Sarumpaet Riris K. "Anak Adalah Harta Yang Berharga". Warta Sumber Hidup, edisi 6. Maret-Mei 2003.

"Utuslah Aku," Year Book, 2012.

Yantzi, Mark. Kekerasan Seksual Dan Pemulihan. Jakarta: BPK Gunung Mulia, 2009.

\section{Internet}

Dewi, "Pelecehan Seksual”, diakses 25 Februari 2013; tersedia di http://dewiberbagiilmukebidanan.blogspot.com/2010/04/peleceha n-seksual.html

\section{Wawancara}

Anggrek. Wawancara Oleh Penulis. Makassar, 28 Mei 2013.

Bintang. Wawancara Oleh Penulis. Makassar, 28 Mei 2013.

Hana, Sarce Rien. Wawancara Oleh Penulis. Makassar, 31 Mei 2013.

Lunanta, Meily. Wawancara Oleh Penulis. Makassar, 28 Mei 2013.

Maiaweng, Peniel C. D.Wawancara Oleh Penulis. Makassar, 30 Mei 2013.

Mawar. Wawancara Oleh Penulis. Makassar, 28 Mei 2013.

Melati. Wawancara Oleh Penulis. Makassar, 31 Mei 2013.

Palar, Ivone. Wawancara Oleh Penulis. Makassar, 28 Mei 2013.

Rafflesia. Wawancara Oleh Penulis. Makassar, 28 Mei 2013.

Tarigan, Simon. Wawancara Oleh Penulis. Makassar, 31 Mei 2013.

Weismann, Ivan. Wawancara Oleh Penulis. Makassar, 30 Mei 2013. 